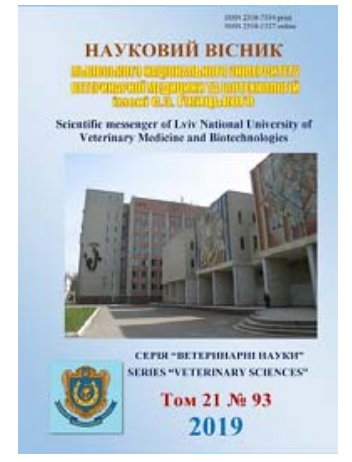

Науковий вісник Дьвівського національного університету ветеринарної медицини та біотехнологій імені С.З. Гжицького.

\author{
Серія: Ветеринарні науки
}

Scientific Messenger of Lviv National University of Veterinary Medicine and Biotechnologies. Series: Veterinary sciences

UDC 619:618.19:616-073

\title{
Morphological changes in cows' mammary gland tissue under chronic form of mastitis
}

\author{
A.Y. Mazurkevych, A.V. Hryshchuk, I.A. Hryshchuk \\ National University of Life and Environmental Sciences of Ukraine, Kyiv, Ukraine
}

Article info

Received 05.02.2019

Received in revised form 12.03 .2019

Accepted 13.03.2019

National University of Life and Environmental Sciences of Ukraine, Heroyiv Oborony Str., 15 , Kyiv, 03041, Ukraine.

Tel.: +38-044-527-83-83 E-mail:amaz@nauu.kiev.ua vet-lubny@ukr.net
Mazurkevych, A.Y., Hryshchuk, A.V., \& Hryshchuk, I.A. (2019). Morphological changes in cows' mammary gland tissue under chronic form of mastitis. Scientific Messenger of Lviv National University of Veterinary Medicine and Biotechnologies. Series: Veterinary sciences, 21(93), 109112. doi: $10.32718 /$ nvlvet9319

Nowadays, there are many different methods for diagnosing cow' mammary gland diseases. This is a clinical examination of the general condition of the animal, organoleptic, physico-chemical, bacteriological research of the secretion of the mammary gland, radiological, ultrasound, laser, histological, cytological diagnostics, etc. Since all these methods in most cases are aimed at evaluating functional changes in the mammary gland and do not reflect the structural changes of the organ, so in the development of therapeutic and preventive measures to prevent the occurrence of pathological processes in the mammary gland in cows do not display information on pathomorphological changes in the tissues of mammary glands for mastitis of various forms. Histological diagnostics becomes an integral part of the clinical examination of animals in the activity of the doctor of veterinary medicine, because it allows taking into account the changes occurring in the tissues of the mammary gland, not only on the macroscopic, but also on the microscopic levels, which is especially important in differential diagnosis. Microscopic studies of biopsy revealed that normally the wall of the lacrimal alveolus consists of a single-layer cubic epithelium, a layer of myoepithelial (basintine) cells, a basement membrane and perialveolar connective tissue that contains numerous blood and lymphatic capillaries and nerve fibers. On the internal walls of the alveoli, there are secretory cells (lactoxytes) which, at different stages of their accumulation of secretion, or its separation into the lumen of the alveoli. The entire lumen of the alveoli is completely filled with a secret, which is rather intensely colored with eosin. In damaged alveoli, we detected the destruction of in situ lacticates, their excretion into the lumen with subsequent destruction there. In the destruction and removal of a small number of lacto-cysts in the lumen of the alveoli was a formed secret, in which an increased number of lactocytes and single neutrophils and lymphocytes were recorded. The given results indicate the pathohistological changes in cows' mammary gland tissues under the chronic form of the mastitis. The method can be used as one of the important tests in the differential diagnosis of mastitis, which makes it possible to carry out in-depth study of the structure of the mammary gland of cows for various types of pathology using the method of biopsy of tissues from the affected area and the histological examination of the biopsy. Histology, as the most important scientific instrument of biology and medicine, is the only way to detect pathological changes in the tissues of the mammary gland. That is why histology of breast pathology serves as the most accurate diagnostic method in veterinary medicine and helps to choose the most effective way of treatment.

Key words: cows, mammary gland, diagnostics, mastitis.

\section{Морфологічні зміни тканини молочної залози у корів при катаральній формі маститу}

А.Й. Мазуркевич, А.В. Грищук, І.А. Грищук

Національний університет біоресурсів і природокористування Украӥни, м. Київ, Украӥна 
На сьогоднішній час існує багато різних методів діагностики хвороб молочної залози у корів. Це і клінічне обстеження загального стану тварини, органолептичне, фізико-хімічне, бактеріологічне дослідження секрету молочної залози, рентгенологічне, УЗД, лазерна, гістологічна, цитологічна діагностика та інш. Але всі изі методи в більшості випадків спрямовані на оцінку функиіональних змін в молочній залозі $і$ зовсім не відображають структурних змін органа, то і в розробці лікувально-профілактичних заходів щзодо запобігання виникнення патологічних процесів у молочній залозі у корів не відображається інформація щзодо патоморфологічних змін в тканинах молочної залози за маститів різних форм. Гістологічна діагностика стає невід'ємною частиною клінічного обстеження тварин в діяльності лікаря ветеринарної медицини, оскільки дозволяє враховувати зміни, які відбуваються в тканинах молочної залози не тільки на макроскопічному, а й на мікроскопічному рівнях. Мікроскопічними дослідженнями біоптату встановлено, щь в нормі стінка молочних альвеол складається із одношарового кубічного епітелію, шару міоепітеліальних (корзинчатих) клітин, базальної мембрани і периальвеолярної сполучної тканини, ццо містить численні кровоносні і лімфатичні капіляри та нервові волокна. На внутрішніх стінках альвеол розмішені секреторні клітини (лактоцити), які у різних стадіях накопичення ними секрету, чи виділення його у просвіт альвеол. Весь просвіт альвеоли повністю заповнений секретом, який досить інтенсивно зафарбовувався еозином. В ушкоджених альвеолах виявляють руйнування лактоцитів іп sіtи, їх злущення в просвіт з наступним там руйнуванням. При руйнуванні та злущуванні невеликої кількості лактоцитів у просвіті альвеол знаходився сформований секрет, в якому реєструвалась підвищена кількість лактоцитів та поодинокі нейтрофіли й лімфоцити. Наведені результати вказують на вивчення патогістологічних змін в тканинах молочної залози корів за хронічної форми маститу. Метод може бути використаний як один із важливих тестів у диференџійній діагностиці маститів, щзо дає можливість здійснювати поглиблене вивчення структури молочної залози корів за різних видів патологї з використанням методу біопсї̈ тканин з ураженої ділянки та гістологічного дослідження отриманого біоптату. Гістологія, як найважливіший науковий інструмент біології і медицини, є єдиним способом виявлення патологічних змін в тканинах молочної залози. А тому гістологія патологій молочної залози служить найбільи точним діагностичним методом у ветеринарї і допомагає вибрати максимально ефективний илях лікування.

Ключові слова: корови, молочна залоза, діагностика, мастит.

\section{Ветуп}

Точна діагностика хвороб - це запорука ефективного лікування тварин. Впровадження новітніх умов та технологій у ветеринарному сервісі потребують нових розробок щодо діагностики, лікування, прогнозування та профілактики незаразних хвороб загалом i хвороб молочної залози у корів зокрема.

Сьогодні існує багато різних методів діагностики хвороб молочної залози у корів. Це і клінічне обстеження загального стану тварини, й органолептичне, фізико-хімічне, бактеріологічне дослідження секрету молочної залози, рентгенологічне, УЗД, лазерна, гістологічна, цитологічна діагностика та інш. (Kharuta et al., 1998; Dmytriv, 2002; Kasianchuk, 2002; Grohn et al., 2004; Martins et al., 2017; Blum et al., 2017; Horiuk et al., 2018).

Оскільки всі ці методи здебільшого спрямовані на оцінку функціональних змін в молочній залозі і зовсім не відображають структурних змін органа, то і в розробці лікувально-профілактичних заходів щодо запобігання виникнення патологічних процесів у молочній залозі в корів не відображається інформація щодо патоморфологічних змін в тканинах молочної залози за маститів різних форм.

Гістологічна діагностика стає невід'ємною частиною клінічного обстеження тварин в діяльності лікаря ветеринарної медицини, оскільки дозволяє враховувати зміни, які відбуваються в тканинах молочної залози не тільки на макроскопічному, а й на мікроскопічному рівнях, що особливо важливо в диференціальній діагностиці (Usha et al., 1991).

Найважливішими ознаками, що стають підставами для дослідження патологічного процесу в молочній залозі корів на клітинному рівні, є поява внутрішньотканинних ущільнень, які виявляються пальпацією або зафіксовані методом УЗД (Mazurkevych et al., 2017). Причому цінність показників гістологічних досліджень залежить від того, яким чином був отри- маний матеріал і наскільки точно визначена для відбору матеріалу ділянка патологічно зміненої тканини.

Мета i завдання дослідження. Встановити патоморфологічні зміни тканин молочної залози корів при катаральній формі маститу за допомогою гістологічного вивчення зразків патологічно змінених тканин, отриманих шляхом прицільної біопсії.

\section{Матеріал і методи досліджень}

Матеріалом для дослідження слугував матеріал, який відбирався із ушкоджених ділянок молочної залози від корів української чорно-рябої молочної породи, хворих на катаральну форму маститу з ураженням однієї із четвертей молочної залози, в господарстві СТОВ “Райз - Максимко” Лубенського району Полтавської області.

Відбір зразків у вигляді біоптату здійснювали під загальною анестезію. За 10 - 15 хв, корові вводили $2 \%$ розчин Ксилазину з розрахунку 0,5 мл на 100 кг маси тіла, а також проводили блокаду за Логвіновим 0,5\% розчином новокаїну. За допомогою УЗ-датчика і апарата УЗД "SLE - 101 РC" визначають місце локалізації патологічно зміненої тканини. Всі процедури 3 проведення біопсії виконуються 3 дотриманням правил асептики та антисептики. Для біопсії використовували напівавтоматичну гільйотинну голку розміром 14Gx20 см виробництва "BIOMEDICA". Після проколу шкіри голку під контролем датчика УЗД просувають до патологічно зміненої ділянки, де здійснюється автоматичний забір тканин. Вся картина відслідковується на моніторі УЗД апарата. Отриманий зразок тканини переносили в $10 \%$ водний розчин нейтрального формаліну для фіксації. Для виготовлення гістозрізів зразки, зафіксовані в розчині формаліну, заливали в парафін. Виготовлені гістозрізи фарбували гематоксиліном Караці й еозином за стандартними прописами (Horalskyi et al., 2011). Мікроструктурні зміни в гістопрепаратах досліджували під світловим 
мікроскопом MC 100LED (Micros Austria) при збільшеннях від 70 до 1000.

\section{Результати та їх обговорення}

За результатами гістологічних досліджень встановлено різницю в будові між функціонально активною та ушкодженою альвеолами (рис.1, А і Б).

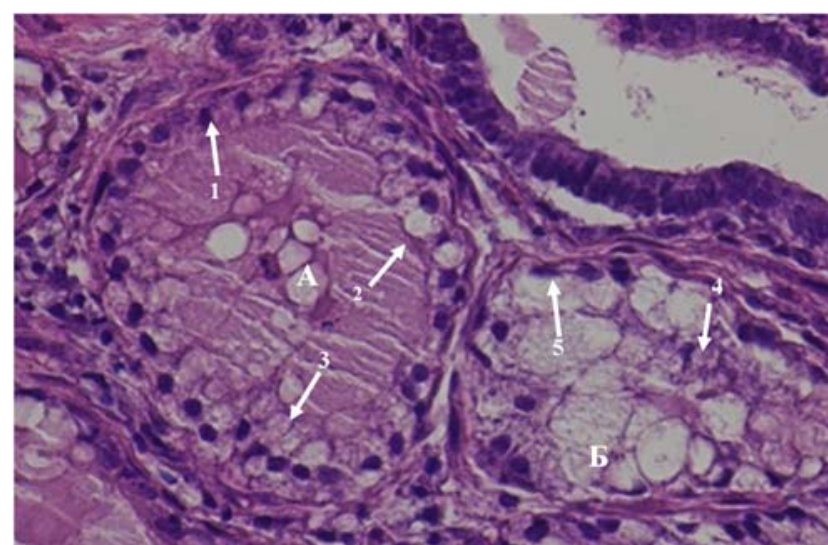

Рис. 1. Мікроскопічна будова молочної залози корови (за результатами дослідження біоптату). А - функціонально активна альвеола: 1 - лактоцит у стані накопичення секрету; 2 - лактоцит, що вже накопичив секрет; 3 - лактоцит у стані виділення секрету. Б альвеола 3 порушенням секреції: 4 - руйнування лактоцита; 5- безпосередній контакт міоепітеліальної клітини $з$ просвітом альвеоли.

Гематоксилін Караці та еозин, $x 400$

Як відомо, паренхіма вимені являє собою складну розгалужену трубчасто-альвеолярну систему, побудовану із часточок (дольок), відокремлених одна від одної міжчасточковою сполучнотканинною стромою, в якій проходять кровоносні судини. Паренхіма кожної часточки представлена численними ацинусами, молочними ходами та внутрішньочасточковими протоками.

Мікроскопічними дослідженнями біоптату встановлено, що в нормі стінка молочних альвеол складається із одношарового кубічного епітелію, шару міоепітеліальних (корзинчатих) клітин, базальної мембрани і периальвеолярної сполучної тканини, що містить численні кровоносні і лімфатичні капіляри та нервові волокна. На внутрішніх стінках альвеол розміщені секреторні клітини (лактоцити), які у різних стадіях накопичення ними секрету чи виділення його у просвіт альвеол. Весь просвіт альвеоли повністю заповнений секретом, який досить інтенсивно зафарбовувався еозином.

В ушкоджених альвеолах нами виявлено руйнування лактоцитів in situ, їх злущення в просвіт 3 подальшим там руйнуванням (рис.1; рис. 2). При руйнуванні та злущуванні невеликої кількості лактоцитів у просвіті альвеол містився сформований секрет, в якому реєструвалась підвищена кількість лактоцитів та поодинокі нейтрофіли й лімфоцити.
При злущуванні та руйнуванні великої кількості лактоцитів епіталіальний шар в альвеолах частково чи повністю зникав. При цьому міоепітеліальні клітини безпосередньо контактували 3 просвітом альвеол, в якому секрет зафарбовувався слабо та нерівномірно, що свідчить про зменшення його кількості та порушення складу (рис. 1).

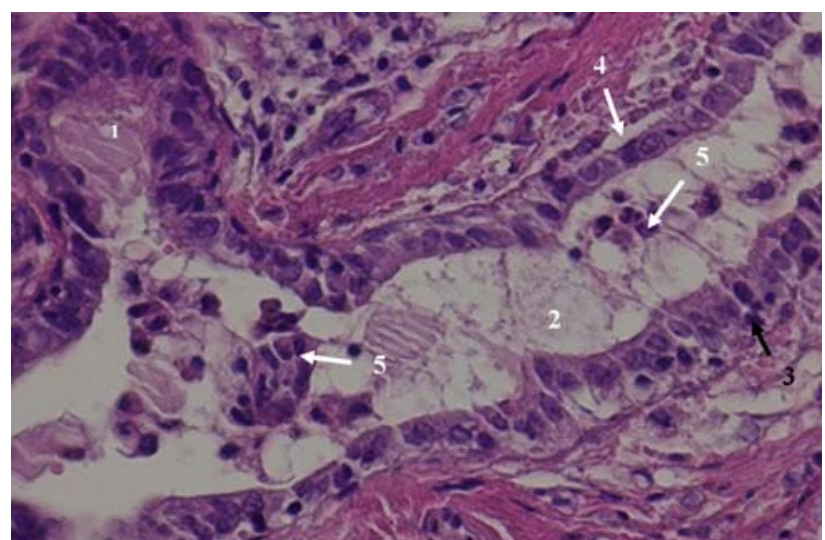

Рис. 2. Мікроскопічна будова патологічно зміненої частини вимені корови при катаральному маститі (за результатами гістологічних досліджень біоптату органа). 1 - альвеола; 2 - внутрішньочасточкова протока; 3 - міжепітеліальний лімфоцит; 4 - субепітеліальний набряк; 5 - злущені лактоцити. Гематоксилін Карайі та еозин, х 400.

В зоні ушкодження зареєстровано збільшення кількості міжепітеліальних лімфоцитів і розвиток субепітеліального набряку, накопичення у внутрішньочасточкових протоках та поява в їх просвіті великої кількості злущених лактоцитів.

У частині часточок реєструвався виразний набряк їх сполучнотканинної строми та збільшення кількості в ній лімофцитів (рис. 3).

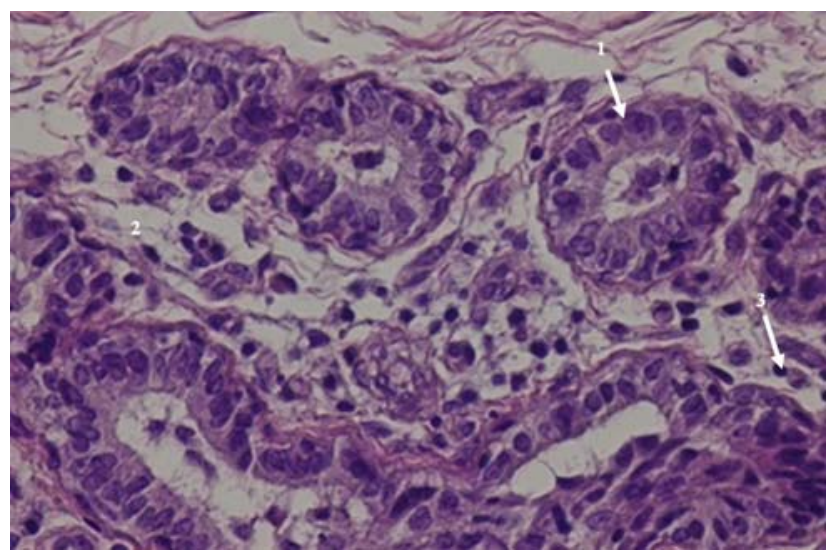

Рис. 3. Мікроскопічна будова патологічно зміненої ділянки молочної залози корови при катаральному маститі (за результатами гістологічних досліджень біоптату органа). 1 - альвеола; 2 - набряк внутрішньочасточкової сполучної тканини; 3 - лімфоцит. Гематоксилін Караці та еозин, х 400

У поодиноких альвеолах молочної залози виявлялось руйнування великої кількості лактоцитів та їх 
некроз. Такі альвеоли були повністю дезорганізовані, а навколо них формувався пояс 3 товстих пучків колагенових волокон (рис. 4).

Поодинокі часточки склерозувались, що супроводжувалось значним зменшенням кількості альвеол, некрозом і злущенням лактоцитів у альвеолах, а також інфільтрацією волокнистої сполучної тканини, що розросталась на місці альвеол, лімфоцитами і поодинокими нейтрофілами (рис. 5).

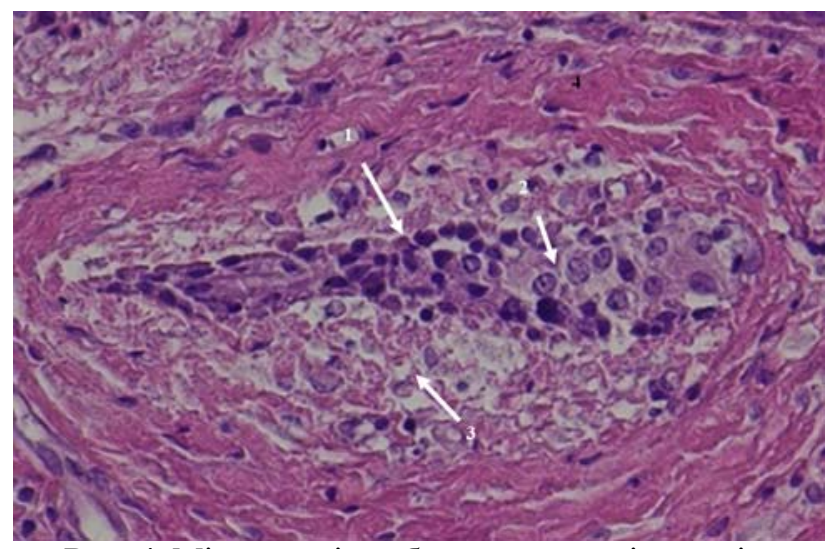

Рис. 4. Мікроскопічна будова патологічно зміненої ділянки молочної залози корови при катаральному маститі (за результатами гістологічних досліджень біоптату органа). 1 - повністю дезорганізована альвеола; 2 - руйнування лактоцитів; 3 - некротизовані клітини; 4 - товсті пучки колагенових волокон. Гематоксилін Караці та еозин, х 400

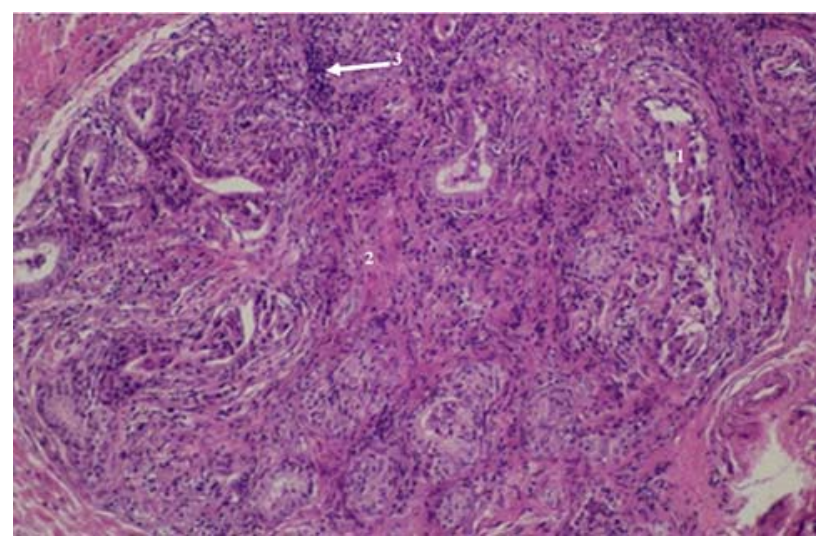

Рис. 5. Мікроскопічна будова патологічно зміненої ділянки молочної залози корови при катаральному маститі (за результатами гістологічних досліджень біоптату органа). 1 - альвеола; 2 - розростання щільної волокнистої сполучної тканини всередині часточки; 3 - скупчення лімфоцитів і нейтрофілів.

Гематоксилін Карацуі та еозин, х 50

\section{Висновки}

Гістологія як найважливіший науковий інструмент біології і медицини є єдиним способом виявлення патологічних змін в тканинах молочної залози. А тому гістологія патологій молочної залози служить найточнішим діагностичним методом у ветеринарії і допомагає вибрати максимально ефективний шлях лікування.

Перспективи подальших досліджень. 3 метою вивчення патоморфологічної картини молочної залози у корів, хворих на катаральний мастит, наступним етапом доцільно провести вивчення морфологічних особливостей за даної патології з використанням гістохімічних методів дослідження.

\section{References}

Blum, S.E., Heller, E.D., Jacoby, S., Krifucks, O., \& Leitner, G. (2017). Comparison of the immune responses associated with experimental bovine mastitis caused by different strains of Escherichia coli. Journal of Dairy Research, 84(2), 190-197. doi: 10.1017/S0022029917000206.

Dmytriv, O.Ia. (2002). Subklinichnyi mastyt u koriv (etiolohiia, patohenez, metody diahnostyky i profilaktyky). Avtor. dys. kand. vet. nauk. L. (in Ukrainian).

Grohn, Y.T., Wilson, D.J., Gonzalez, R.N., Hertl, J.A., Schulte, H., Bennett, G., \& Schukken, Y.H. (2004). Effect of pathogen-specific clinical mastitis on milk yield in dairy cows. Journal of dairy science, $87(10)$, 3358-3374. doi: 10.3168/jds.S0022-0302(04)73472-4.

Horalskyi, L.P., Khomych, V.T., \& Kononskyi, O.I. (2011). Osnovy histolohichnoi tekhniky i morfofunktsionalni metody doslidzhennia u normi ta pry patolohii: navch. posib. Zhytomyr: Polissia (in Ukrainian).

Horiuk, Yu.V., Kukhtyn, M.D., Perkiy, Yu.B., \& Horiuk, V.V. (2018). Distribution of main pathogens of mastitis in cows on dairy farms in the western region of Ukraine. Scientific Messenger of Lviv National University of Veterinary Medicine and Biotechnologies, 20(83), 115-119. doi: 10.15421/nvlvet8322.

Kasianchuk, V.V. (2002). Imunofermentna diahnostyka subklinichnoho mastytu u koriv u pisliarodovyi period. Visnyk Bilotserkiv. derzh. ahrar. un-tu, 23, 66-74 (in Ukrainian).

Kharuta, H.H., Podvaliuk, D.V., Kraievskyi, A.I. ta in. (1998). Metody doslidzhennia statevykh orhaniv i molochnoi zalozy u velykoi rohatoi khudoby. Bila Tserkva (in Ukrainian).

Martins, C.M.M.R., Pinheiro, E.S.C., Gentilini, M., Benavides, M.L., \& Santos, M.V. (2017). Efficacy of a high free iodine barrier teat disinfectant for the prevention of naturally occurring new intramammary infections and clinical mastitis in dairy cows. Journal of Dairy Science, 100(5), 3930-3939. doi: 10.3168/jds.2016-11193.

Mazurkevych, A.I., Hryshchuk, A.V., \& Hryshchuk, I.A. (2017). Doslidzhennia molochnoi zalozy koriv z vykorystanniam me-todu UZD. Naukovo-tekhnichnyi biuleten DNDKIVPKD, 18, 148-152 (in Ukrainian).

Usha, B.V., Zajcev, E.A., \& Jacura, T.M. (1991). Gistologicheskie issledovanie vymeni korov pri mastite. Veterinarija, 4, 45-46 (in Russian). 